18. Фисюнов А.В. Сорные растения. М., 1984. 320 с.

19. Ter Braak C.J.F., Šmilauer P. Reference manual and CanoDraw for Windows User's guide: Software for Canonical Commuhity Ordination (version 4.5). Microcomputer Power. Ithaca, NY, USA, 2002. 500 p.

20. Королюк А.Ю. Экологические оптимумы растений юга Сибири // Ботанические исследования Сибири и Казахстана. 2006. Вып. 12. С. 3-38.

21. Плохинский Н.А. Биометрия. М., 1970. 367 с.

22. Лунева Н.Н., Филиппова Е.В. Постоянство присутствия видов сорных растений в посевах сель- скохозяйственных культур в Ленинградской области // Сорные растения в изменяющемся мире: актуальные вопросы изучения разнообразия, происхождения, эволюции: первая междунар. науч. конф. СанктПетербург, 6-8 декабря 2011 г. СПб.: ВИР, 2011. C. 209-215.

Исследования проводятся при поддержке РФФИ (проект № 17-44-020402 p_a) и средств государственного бюджета (№̄ AAAA-A18118011990151-7).

\title{
MAIN WEED SPECIES OF THE REPUBLIC OF BASHKORTOSTAN: POSITION ON ENVIRONMENTAL GRADIENTS AND AGROBIOLOGICAL GROUPS
}

(C) 2018

Khasanova Gulnaz Rimovna, candidate of biological sciences, associate professor of Soil Science, Botany and Selection Department

Bashkir State Agrarian University (Ufa, Russian Federation)

Yamalov Sergey Maratovich, doctor of biological sciences,

leading researcher of Wild-Growing Flora and Herbasceous Plants Introduction Laboratory

Lebedeva Maria Vladimirovna, candidate of biological sciences, senior researcher of Tropical and Subtropical Plants Group

South-Ural Botanical Garden-Institute of the Ufa Federal Research Centre of Russian Academy of Sciences

(Ufa, Russian Federation)

Abstract. The paper presents a study of the main weed species in the Republic of Bashkortostan according to the results of a floristic analysis of 1170 geobotanical releves. The authors define 30 species, their constancy is more than 20\%. Five species of dicotyledonous and 1 species of monocotyledonous plants Convolvulus arvensis, Chenopodium album, Cirsium setosum, Fallopia convolvulus, Avena fatua, Sonchus arvensis are characterized with the greatest values of occurrence (higher than 50\%). According to the results of the ordination analysis and ANOVA the considered species are well differentiated on the gradients of the factors of moistening, richness of the soil and a crop. Among agrobiological groups of weed species the annual and creeping-rooted weeds prevail.

Keywords: weed species; weed vegetation; environmental factors; agrophytocenosis; CCA-ordination; ANOVA; edapho-climatic factor; agrocoenotic factor; Republic of Bashkortostan; Southern Ural; floristic composition; activity of species; agrobiological groups; ecological scales.

\section{ОЦЕНКА ЭКОЛОГО-ГЕОХИМИЧЕСКОГО СОСТОЯНИЯ ПОЧВ И ЗАПЫЛЕННОСТИ АТМОСФЕРНОГО ВОЗДУХА В СЕЛИТЕБНОЙ ЗОНЕ ЦЕНТРА ГОРНОРУДНОЙ ПРОМЫШЛЕННОСТИ}

(C) 2018

Хасанова Резеда Фиргатовна, доктор биологических наук, ведущий научный сотрудник лаборатории экологии и рационального природопользования; доцент кафедры естественных наук

Семенова Ирина Николаевна, доктор биологических наук, старший научный сотрудник лаборатории экологии и рационального природопользования; профессор кафедры естественных наук

Сибайский филиал Института стратегических исследований Республики Башкортостан

(2. Сибай, Республика Башкортостан, Российская Федераџия); Сибайский институт (филиал)

Башкирского государственного университета (г. Сибай, Республика Башкортостан, Российская Федерация)

Рафикова Юлия Самигулловна, кандидат биологических наук,

старший научный сотрудник лаборатории экологии и рационального природопользования

Сибайский филиал Института стратегических исследований Республики Башкортостан

(2. Сибай, Республика Башкортостан, Российская Федерация)

Суюндуков Ялиль Тухватович, доктор биологических наук, главный научный сотрудник

лаборатории экологии и рационального природопользования; заместитель директора по научной работе

Сибайский филиал Института стратегических исследований Республики Башкортостан

(2. Сибай, Республика Башкортостан, Российская Федеращия); Сибайский институт (филиал)

Башкирского государственного университета (2. Сибай, Республика Башкортостан, Российская Федерация)

Ильина Ирина Валерьевна, кандидат биологических наук, доцент кафедры ботаники Сибайский институт (филиал) Башкирского государственного университета

(2. Сибай, Республика Башкортостан, Российская Федеращия)

Аннотащия. Изучено содержание тяжелых металлов (ТМ) в почвах селитебных зон г. Сибай - центра горнорудной промышленности юго-востока Республики Башкортостан. Показано, что в почвах под травянистой 
растительностью наблюдается повышенное содержание ряда ТМ, таких как медь, цинк и кадмий. В то же время участки, расположенные под кроной Betula pendula Roth., в меньшей степени загрязнены TM по сравнению с открытыми площадками. Пониженное содержание ряда металлов (железа, кадмия, кобальта и подвижных форм никеля) в почвах под кроной $B$. pendula Roth. подтверждает барьерную роль древесных растений, защищающих почву от аэрогенного поступления токсикантов. Проведенное исследование показало перспективность использования березы повислой в качестве вида аккумулянта-фиторемедианта при озеленении городских территорий горнорудного региона Республики Башкортостан. Исследования содержания ТМ в органах и тканях показали, что представители вида B. pendula Roth., произрастающие на территории г. Сибай, способны накапливать значительное количество фитотоксикантов, в особенности цинка, содержание которого варьировало в пределах 1041-1855 мг/кг. Одним из источников повышенного содержания ТМ в листьях и коре деревьев является пыль. В работе проведено сравнительное изучение запыленности листьев берез, произрастающих в центральной части города с интенсивным движением автотранспорта и в окрестностях Сибайского карьера, разрабатывающего месторождение медно-цинковой руды. Количество пыли на листьях, собранных вблизи отвалов Сибайского карьера, составляло $3,53 \pm 0,64$ г/м², что меньше, чем в центральной части города, где это показатель достигал 41,04 $\pm 10,38$ г/м². Очевидно, это связано с тем, что отвалы Сибайского карьера расположены на открытой и интенсивно проветриваемой местности, что и объясняет сильное рассеивание пыли. В то же время частицы пыли вблизи отвалов карьера в значительно большей степени загрязнены марганцем, кобальтом и кадмием по сравнению с центральной частью города.

Ключевые слова: тяжелые металлы; поллютанты; предельно допустимая концентрация; региональный геохимический фон; горнорудная промышленность; запыленность атмосферного воздуха; экологический мониторинг; почвы; древесные растения; береза повислая; травянистая растительность; город Сибай; Республика Башкортостан.

\section{Введение}

Экологическая ситуация в целом ряде регионов Российской Федерации на современном этапе вызывает тревогу. Это обусловлено повышенной нагрузкой антропогенного характера, прежде всего на территории урбанизированных систем, которые испытывают постоянное влияние техногенных геохимических потоков загрязняющих веществ, созданных выбросами, стоками и отходами промышленных предприятий, коммунально-бытовых объектов и автотранспорта [1, с. 33; 2, с. 340].

Особое значение имеет загрязнение промышленного города тяжелыми металлами (ТM). Важнейшими источниками ТМ являются горнорудная промышленность, черная и цветная металлургия, сжигание минерального топлива [3, с. 93]. Добыча руды приводит к потерям ее частиц. Кроме того, под действием ветра частицами такого рода загрязняются обширные области вокруг шахт и карьеров, особенно в наветренном направлении [4, с. 346]. Во время обработки руд для извлечения металлов они попадают на земную поверхность путем выброса из труб плавильных печей [4, с. 347]. Массовые взрывы на карьерах являются крупными источниками пыли и ядовитых газов. Почвы и поверхностные воды на территориях, прилегающих к отвалам карьеров по добыче полиметаллических руд, загрязнены ТМ. Вследствие выветривания горных пород, складированных в отвалы, усиливается запыленность воздуха и происходит резкое ухудшение жизненных условий [3, с. 23].

Запыленность атмосферного воздуха - важнейший экологический фактор, играющий существенную роль в развитии ряда заболеваний. Многими авторами подтверждены корреляционные взаимосвязи, доказывающие влияние качества воздушной среды на заболеваемость населения [5-7]. Выявлено достоверное влияние загрязнения атмосферного воздуха на увеличение таких заболеваний, как бронхит, пневмония, эмфизема легких [5], а также на снижении сопротивляемости организма, что сказывается на росте инфекционных и респираторных заболеваний [8]. Проведение специальных исследований в горо- дах и регионах России доказало, что главным фактором риска на здоровье человека является загрязнение атмосферного воздуха взвешенными веществами, который обусловливает рост смертности населения [9].

В промышленных городах высокая запыленность способствует росту в атмосфере взвешенных частиц, которые являются носителями химических элементов. Различают два типа атмосферной техногенной нагрузки - это выпадение большого количества пыли с низким содержанием химических элементов и выпадение меньшего количества пыли с высоким содержанием поллютантов [2, с. 376].

Город Сибай с населением более 60 тысяч человек, расположенный на юго-востоке Республики Башкортостан, является промышленным центром с функционирующими в течение более полувека горнорудными предприятиями по добыче и переработке медно-цинковой руды. На территории города сформированы две промышленно-коммунальные зоны: юго-западная (Сибайский карьер и шахта, отвалы пустой породы) и восточная (Сибайская обогатительная фабрика, хвостохранилище, Зауральская ТЭЦ). В южной части города находится свалка твердых бытовых отходов. В центральной и южной части города расположен основной исторически сложившийся массив жилой застройки, связанный узкой полосой с северной частью. Селитебная территория состоит из нескольких частей: центр города, с примыкающим к нему с юга жилым районом, и частный сектор, включающий ряд обособленных микрорайонов: на югозападе - «Горный» и «Южный», на западе - «Золото», на севере - «Обогатителей», на северо-западе «Аркаим». Относительно недавно на востоке города вырос микрорайон «Восточный», на севере и северовостоке - микрорайоны «Северный» и «Сарматы».

В настоящее время развитие города набирает темпы, застраиваются и осваиваются свободные территории, все это способствует сокращению зеленых насаждений. Частые ветры в степном Зауралье способствуют дефляции пылевидных частиц с отвалов карьера и хвостохранилищ обогатительной фабрики, расположенных практически на территории города. Имеющиеся зеленые насаждения города не справля- 
ются с задержанием пыли из воздуха, в результате чего создается неблагоприятная экологическая обстановка.

Одним из крупнейших горнодобывающих предприятий цветной металлургии города является Сибайский филиал ОАО «Учалинский ГОК», который функционирует на базе медноколчеданных месторождений. В радиусе 2-5 км вокруг производственных объектов обогатительного комбината отмечаются высокие концентрации валовых и подвижных форм $\mathrm{Zn}, \mathrm{Cu}, \mathrm{Cd}$ и $\mathrm{Fe}$. На антропогенно нарушенных участках выявлены аномальные содержания ТМ в почвах, превышающие ОДК в 2-8 раз [10].

В наземные цепи питания ТМ вводятся преимущественно через растения, которые мобилизуют эти элементы из загрязненной почвы [11, с. 739]. Одним из часто встречающихся видов, используемых в озеленении г. Сибай, является Betula pendula Roth. Известно, что данный вид проявляет устойчивость к ряду тяжелых металлов. Так, у популяций березы была обнаружена металлотолерантность к цинку и свинцу [12-14]. Металлоустойчивость березы также доказывают результаты исследований, свидетельствующие о том, что относительное жизненное состояние насаждений березы повислой, произрастающей на отвалах карьера по разработке медно-колчеданного месторождения (г. Учалы, Республика Башкортостан), оценивалось как «здоровое» [15].

Цель настоящего исследования: изучение эколого-геохимического состояния почв г. Сибай на открытых участках и под древесными растениями, пылеулавливающей способности и накопления ТМ в органах B. pendula Roth.

\section{Материал и методы}

Для оценки эколого-геохимического состояния селитебных территорий г. Сибай были отобраны почвы в центральной части города и в микрорайонах «Золото», «Аркаим», «Сарматы», «Южный», «Горный», «Обогатителей», «Восточный» как под травянистой растительностью, так и под кроной B. pendula Roth. в радиусе 1 м от ствола.

Исходный почвенный покров данной территории был представлен в основном черноземами обыкновенными тяжелосуглинистыми. Выбранные для данного исследования пробные площадки отнесены нами к антропогенно преобразованным почвам с измененной верхней частью и ненарушенной средней или нижней частью профиля. Отбор почвенных проб производился на открытых участках между жилыми застройками из слоя 0-10 см в течение летнего периода 2017 г. методом конверта, подготовка к анализу проводилась общепринятыми методами [16, с. 6]. Образцы почвы высушивали, просеивали через нейлоновое сито с диаметром пор $\leq 1$ мм и тщательно перемешивали. 0,2 г почвы расщепляли смесью концентрированных кислот $\left(\mathrm{HF} / \mathrm{HNO}_{3} / \mathrm{HCl}=3: 1: 1\right)$, поэтапно нагревали до температуры $160 \pm 10^{\circ} \mathrm{C}$ и выпаривали смесь досуха. К сухому остатку добавляли 1 мл концентрированной азотной кислоты, 20 мл бидистиллированной воды и кипятили до уменьшения объема примерно в два раза. Полученный раствор фильтровали и затем разбавляли до 50 мл бидистиллированной водой. Рабочие растворы для измерения массовой концентрации металлов готовили из Государственных стандартных образцов. Подвижные формы экстрагировали ацетатно-аммонийным буферным раствором (ААБ) с рН 4,8.

Экологическую оценку запыленности воздуха города Сибай проводили путем исследования содержания пыли на листьях B. pendula Roth. [17, с. 135]. Сбор материала в объеме 1320 листьев (44 дерева, 30 листьев с каждого дерева) проводили на главных улицах города с наиболее интенсивным движением автотранспорта, а также в окрестностях отвалов Сибайского карьера. Исследования проводили в лабораторных условиях путем смыва пыли с листьев дистиллированной водой в стеклянные стаканчики, раствор фильтровали, фильтры высушивали в течение суток и взвешивали на аналитических весах ВК - 150,1.

Массу пыли определяли по разнице в массе осадка на фильтровальной бумаге, предварительно высушенной в сушильном шкафу и взвешенной. Площадь листа высчитывали путем обмера листовых пластинок вдоль и поперек и умножением на поправочный коэффициент, который определяется весовым методом путем взвешивания кальки площадью $100 \mathrm{~cm}^{2}$ и взвешивания вырезанного из кальки контура листа.

Для определения концентрации металлов в почве и в пыли (Cd, $\mathrm{Co}, \mathrm{Cu}, \mathrm{Ni}, \mathrm{Pb}, \mathrm{Fe}, \mathrm{Mn}$ и $\mathrm{Zn})$ был использован метод атомно-абсорбционной спектрофотометрии (спектрофотометр Contr AA, Analytik Jena).

Для токсикологической оценки почв использовали предельно-допустимые концентрации (ПДК) ТМ по их валовым и подвижным формам [18], региональный геохимический фон (РГФ) [19] и почвенные кларки [20].

Отбор растительных образцов проводили в августе 2017 г. с деревьев B. pendula Roth. примерно 20летнего возраста на высоте 1,3 м от земли. Образцы высушивали и измельчали на мельнице. Содержание ТМ в растениях определяли методом атомно-абсорбционной спектрофотометрии после сухого озоления в муфельной печи при $500^{\circ} \mathrm{C}$ и последующего перевода золы в раствор $\mathrm{HCl}$.

Математическую обработку данных проводили с помощью общепринятых методов вариационной статистики с использованием пакета программ Microsoft Excel и Statistica 6.0. Приводятся следующие статистические показатели: $\mathrm{n}$ - количество образцов, $\mathrm{M}$ средняя арифметическая, $\mathrm{m}$ - ошибка средней арифметической, $\min$ и $\max$ - минимальное и максимальное значения, $\mathrm{p}$ - уровень значимости, $\mathrm{Cv}$ - коэффициент вариации.

Достоверность различий оценивали по распределению Стьюдента на доверительном уровне $95 \%$.

\section{Результаты исследований и их обсуждение}

Сравнительное изучение содержания металлов в почвах на открытых участках и под древесными растениями

Анализ почв селитебной зоны г. Сибай выявил превышение ПДК по валовому содержанию меди и цинка и по подвижным формам меди в пробах, отобранных как на открытых участках под травянистой растительностью (в 3,0, 2,3 и в 16,3 раза соответственно), так и на участках под кроной березы повислой (в 3,8, 1,1 и в 12,4 раза соответственно) (табл. 1). 
Хасанова Р.Ф., Семенова И.Н., Рафикова Ю.С., Суюндуков Я.Т., Ильина И.В. 03.02.00 - общая биология Оценка эколого-геохимического состояния почв и запыленности атмосферного воздуха...

Таблица 1 - Концентрация тяжелых металлов в поверхностном слое почв г. Сибай, мг/кг

\begin{tabular}{|c|c|c|c|c|}
\hline \multirow{2}{*}{ TM } & Под кроной B. pendula & Под травянистой растительностью & \multirow[b]{2}{*}{$\mathrm{p}$} & \multirow{2}{*}{$\begin{array}{c}\text { ПДК/РГФ/кларк*, } \\
\text { ПДК** }\end{array}$} \\
\hline & \multicolumn{2}{|r|}{$\mathrm{M} \pm \mathrm{m}$} & & \\
\hline \multicolumn{5}{|c|}{ Валовые формы } \\
\hline $\mathrm{Cu}$ & $209,5 \pm 69,5$ & $165,7 \pm 48,6$ & 0,622 & $55 / 49 / 47$ \\
\hline $\mathrm{Zn}$ & $109,3 \pm 49,1$ & $234,0 \pm 41,5$ & 0,091 & $100 / 223 / 83$ \\
\hline $\mathrm{Fe}$ & $7586,9 \pm 135,5$ & $15782,8 \pm 1582,0$ & 0,0063 & $-/ 2500 / 46500$ \\
\hline $\mathrm{Ni}$ & $42,7 \pm 5,2$ & $47,8 \pm 5,2$ & 0,563 & $85 / 58,7 / 58$ \\
\hline Mn & $1031,8 \pm 62,5$ & $871,0 \pm 285,4$ & 0,722 & $1500 / 525,4 / 690$ \\
\hline $\mathrm{Pb}$ & $14,1 \pm 1,3$ & $20,8 \pm 2,5$ & 0,114 & $32 / 20 / 16$ \\
\hline $\mathrm{Cd}$ & $0,2 \pm 0,1$ & $7,1 \pm 0,7$ & 0,000047 & $2,0 / 1,5 / 0,13$ \\
\hline Co & $12,5 \pm 2,6$ & $29,6 \pm 3,2$ & 0,00077 & $15,0 / 16,2 / 12$ \\
\hline \multicolumn{5}{|c|}{ Подвижные формы } \\
\hline $\mathrm{Cu}$ & $37,3 \pm 15,3$ & $45,8 \pm 8,8$ & 0,510 & 3,0 \\
\hline $\mathrm{Zn}$ & $23,8 \pm 14,4$ & $87,3 \pm 11,4$ & 0,008 & 23,0 \\
\hline $\mathrm{Fe}$ & $1378,6 \pm 224,4$ & $6276,1 \pm 731,6$ & 0,001 & - \\
\hline $\mathrm{Ni}$ & $3,7 \pm 0,8$ & $17,6 \pm 1,9$ & 0,0006 & 4,0 \\
\hline $\mathrm{Mn}$ & $91,1 \pm 14,5$ & $319,6 \pm 105,7$ & 0,188 & 140 \\
\hline $\mathrm{Pb}$ & $3,4 \pm 1,3$ & $15,0 \pm 9,1$ & 0,425 & 6,0 \\
\hline $\mathrm{Cd}$ & $0,03 \pm 0,00$ & $0,9 \pm 0,2$ & 0,026 & 0,2 \\
\hline Co & $3,8 \pm 1,0$ & $8,0 \pm 0,7$ & 0,006 & 5,0 \\
\hline
\end{tabular}

Примечания. * для валовых форм ТМ, ** для подвижных форм ТМ; жирным показаны значения, достоверно различающиеся при $p<0,01$.

Валовое содержание кадмия и кобальта в почвах на участках, покрытых травой, превышало РГФ в 4,7 и 1,8 раза соответственно, в то время как на участках под древесными растениями эти показатели были достоверно ниже $(p<0,01)$ и соответствовали уровню кларка [20].

Концентрация подвижных форм цинка, никеля, кадмия и кобальта в почвах под травянистой растительностью превышала как ПДК (соответственно, в $3,8,4,4,4,5$ и 1,6 раза), так и их содержание в почвах под березой (разница достоверна при $p<0,01$ ).

Содержание подвижного марганца и свинца также было выше ПДК в почвах на открытых участках, в то время как достоверных различий между концентрацией этих металлов в почвах под травянистой растительностью и под деревьями выявлено не было. Данный факт подтверждает значение зеленых насаждений в качестве барьера, защищающего почву от аэрогенного поступления токсикантов.

\section{Изучение содержания металлов в органах} и тканях B. pendula Roth.

В ряде исследований отмечались различия в концентрации металлов между различными тканями и органами деревьев $[21 ; 22]$. Как правило, концентрации металлов в листьях выше, чем в коре. На основании полученных данных, представленных в таблице 2, был проведен сравнительный анализ накопления ТМ в органах и тканях B. pendula Roth., произрастающих в селитебной зоне г. Сибай.

Таблица 2 - Среднее содержание ТМ в органах B. pendula Roth., мг/кг

\begin{tabular}{|c|c|c|c|c|c|}
\hline \multirow{2}{*}{ TM } & \multicolumn{3}{|c|}{ Содержание, мг/кг } & \multirow{2}{*}{$\begin{array}{c}\text { Оптимальная } \\
\text { концентрация }\end{array}$} & фитотоксичная концентрация \\
\cline { 2 - 4 } & в листьях & в коре (бересте) & в лубе & $5-30[23]$ & $150[23], 10-20[24$, с. 28$]$ \\
\hline $\mathrm{Cu}$ & $16,92 \pm 5,87$ & $11,50 \pm 3,50$ & $4,63 \pm 0,88$ & - \\
\hline $\mathrm{Zn}$ & $1041,50 \pm 254,50$ & $1740,50 \pm 497,50$ & $1855,25 \pm 769,75$ & $150-300[23]$ & $750[23]$ \\
\hline $\mathrm{Fe}$ & $358,58 \pm 11,55$ & $606,88 \pm 394,13$ & $336,50 \pm 49,25$ & $20-300[23]$ & $10-100[23]$ \\
\hline $\mathrm{Ni}$ & $13,42 \pm 0,36$ & $11,50 \pm 3,5$ & $8,13 \pm 0,13$ & $0,1-5,0[23]$ & $500[23]$ \\
\hline $\mathrm{Mn}$ & $230,83 \pm 136,25$ & $117,25 \pm 12,75$ & $194,25 \pm 147,50$ & $25-250[23]$ & - \\
\hline $\mathrm{Pb}$ & $3,51 \pm 2,54$ & $6,00 \pm 3,0$ & $1,84 \pm 0,41$ & до $10[25]$ & $1,0-70,0[26]$ \\
\hline $\mathrm{Cd}$ & $1,43 \pm 0,44$ & $1,81 \pm 0,48$ & $1,24 \pm 0,71$ & $0,05-0,6[26]$ & - \\
\hline $\mathrm{Co}$ & $3,67 \pm 0,55$ & $4,25 \pm 0,50$ & $2,13 \pm 0,13$ & $0,5-3,0[27]$ & \\
\hline
\end{tabular}

В органах и тканях березы выявлен повышенный уровень цинка, железа, никеля, кадмия и кобальта.

Сравнительное исследование содержания ТМ в органах и тканях березы повислой свидетельствует об их избирательности по отношению к определенным химическим элементам. Изученные металлы по содержанию сформировали следующий убывающий ряд: в листьях $\mathrm{Zn}>\mathrm{Fe}>\mathrm{Mn}>\mathrm{Cu}>\mathrm{Ni}>\mathrm{Pb}=\mathrm{Co}>$ $>\mathrm{Cd}$; в коре $\mathrm{Zn}>\mathrm{Fe}>\mathrm{Mn}>\mathrm{Cu}=\mathrm{Ni}>\mathrm{Pb}>\mathrm{Co}>\mathrm{Cd}$ и в лубе $\mathrm{Zn}>\mathrm{Fe}>\mathrm{Mn}>\mathrm{Ni}>\mathrm{Cu}>\mathrm{Co}>\mathrm{Pb}>\mathrm{Cd}$. Отличия выявлены в содержании меди, никеля, свинца и кобальта. Так, в листьях содержание меди превыша- ет содержание никеля, в коре эти показатели равны, в лубе содержание никеля превышает содержание меди; в листьях содержание свинца одинаково с содержанием кобальта, в коре содержание свинца выше, чем кобальта, в лубе, наоборот, содержание кобальта выше, чем свинца.

По содержанию ТМ исследованные органы и ткани березы повислой располагались в следующем порядке (по убыванию): $\mathrm{Cu}, \mathrm{Mn}, \mathrm{Ni}-$ листья > кора > $>$ луб; $\mathrm{Zn}$ - луб > кора > листья, $\mathrm{Fe}, \mathrm{Cd}, \mathrm{Pb}$ и $\mathrm{Co}-$ кора $>$ листья $>$ луб. Таким образом, медь, марганец, никель накапливались преимущественно в листьях, 
железо, свинец, кадмий и кобальт - в лубе, цинк - в лубе и коре.

Выполненные исследования показали, что представители вида B. pendula Roth., произрастающие на территории г. Сибай, испытывают сильное техногенное воздействие. В условиях полиметаллического загрязнения надземные органы березы повислой способны накапливать значительное количество фитотоксикантов, что свидетельствует о перспективности ее использования в качестве вида аккумулянта-фиторемедианта при озеленении городских территорий Зауральского региона Республики Башкортостан.

Изучение пылезадерживающей способности листовой пластины B. pendula Roth.

в условиях г. Сибай

Листья растений являются естественными планшетами-накопителями аэрозольного материала. При этом количество пыли на листовой пластине прямо пропорционально ее площади, а также зависит от ее поверхности: шершавые, складчатые, опушенные, липкие листья осаждают и удерживают большее количество пыли, чем гладкие. Метод взвешивания позволяет определить пылезадерживающую способность растений лишь частично, поскольку часть пыли сдувается ветром и смывается осадками. Для пол- ной оценки пылезадерживающей способности растений требуются длительные обследования на стационаре. Однако и разовые наблюдения могут дать некоторое представление о способности растения задерживать и осаждать из воздуха пылеватые частицы [28].

Результаты определения пылезадерживающей способности B. pendula Roth. в условиях г. Сибай представлены в таблице 3 .

Из представленных данных видно, что средние показатели накопления пыли в г. Сибай колеблются

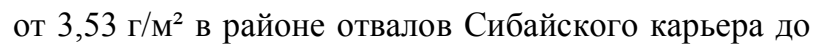
48,90 г/м² - на ул. Белова. Наиболее «чистой» территорией центральной части города являются ул. Чайковского и ул. Ленина.

Листья березы, собранные вблизи отвалов Сибайского карьера, в минимальном количестве накапливают пыль. Данный факт может быть обусловлен тем, что отвалы Сибайского карьера располагаются за чертой город на открытой и интенсивно проветриваемой местности, чем и объясняется сильное рассеивание пыли.

Содержание тяжелых металлов в пыли

Содержание ТМ в накапливаемой на листьях деревьев пыли представлено в таблице 4.

Таблица 3 - Сравнительная оценка массы пыли на листьях B. pendula Roth. на улицах г. Сибай, г/м²

\begin{tabular}{|l|c|c|c|c|}
\hline \multicolumn{1}{|c|}{ Место отбора } & $\mathrm{M} \pm \mathrm{m}$ & $\mathrm{Min} \div \max$ & $\mathrm{Cv}, \%$ & $\mathrm{p}$ \\
\hline ул. Белова $(\mathrm{n}=9)$ & $48,90 \pm 16,14$ & $7,28 \div 131,89$ & 33,0 & 0,08 \\
\hline ул. Чайковского $(\mathrm{n}=6)$ & $8,62 \pm 2,37 *$ & $3,25 \div 18,59$ & 27,5 & $0,045^{*}$ \\
\hline пр. Горняков $(\mathrm{n}=11)$ & $41,04 \pm 10,38^{*}$ & $8,88 \div 99,51$ & 25,3 & $0,043^{*}$ \\
\hline ул. Ленина $(\mathrm{n}=10)$ & $9,87 \pm 0,45^{*}$ & $4,85 \div 18,59$ & 16,75 & $0,009^{*}$ \\
\hline Отвалы Сибайского карьера $(\mathrm{n}=8)$ & $3,53 \pm 0,64$ & $0,34 \div 3,25$ & 42,4 & - \\
\hline
\end{tabular}

Примечание. * статистически значимое различие между содержанием пыли на листьях березы повислой, произрастающей в окрестностях отвалов Сибайского карьера и в городе.

Таблица 4 - Концентрация металлов в пыли, находящейся на поверхности листовой пластины $B$. pendula Roth., мг/кг

\begin{tabular}{|l|c|c|c|c|c|c|c|c|}
\hline \multirow{2}{*}{ Место отбора } & \multicolumn{9}{c|}{ Металлы и их содержание } \\
\cline { 2 - 11 } & $\mathrm{Cu}$ & $\mathrm{Zn}$ & $\mathrm{Ni}$ & $\mathrm{Mn}$ & $\mathrm{Co}$ & $\mathrm{Pb}$ & $\mathrm{Cd}$ & $\mathrm{Fe}$ \\
\hline ул. Белова & 7,51 & 154,2 & 0,43 & 27,9 & 0,21 & 0,38 & 0,04 & 63,23 \\
\hline ул. Чайковского & 8,61 & 112,8 & 2,11 & 32,35 & 0,19 & 0,94 & 0,06 & 112,75 \\
\hline пр. Горняков & 12,54 & 13,02 & 1,56 & 41,00 & 0,21 & 1,25 & 0,003 & 170,31 \\
\hline ул. Ленина & 9,38 & 85,94 & 1,65 & 32,95 & 0,24 & 1,25 & 0,06 & 152,75 \\
\hline Отвалы Сибайского карьера & 13,78 & 157,30 & 2,21 & 93,62 & 1,96 & 1,10 & 1,26 & 154,31 \\
\hline
\end{tabular}

Содержание металлов в пыли на листьях березы повислой на ул. Чайковского располагалось в следующий убывающий ряд: $\mathrm{Zn}=\mathrm{Fe}>\mathrm{Mn}>\mathrm{Cu}>\mathrm{Ni}>$ $>\mathrm{Pb}>\mathrm{Co}>\mathrm{Cd}$, на улице Ленина $-\mathrm{Fe}>\mathrm{Zn}>\mathrm{Mn}>$ $>\mathrm{Cu}>\mathrm{Ni}>\mathrm{Pb}>\mathrm{Co}>\mathrm{Cd}$.

Содержание металлов в пылевых частицах на более загрязненной городской территории можно расположить следующим образом: на улице Белова $\mathrm{Zn}>\mathrm{Fe}>\mathrm{Mn}>\mathrm{Cu}>\mathrm{Ni}>\mathrm{Pb}>\mathrm{Co}>\mathrm{Cd}$, на пр. Горняков $-\mathrm{Fe}>\mathrm{Mn}>\mathrm{Zn}>\mathrm{Cu}>\mathrm{Ni}>\mathrm{Pb}>\mathrm{Co}>\mathrm{Cd}$.

В окрестностях отвалов Сибайского карьера ряд металлов выглядит следующим образом: $\mathrm{Zn}>\mathrm{Fe}>$ $>\mathrm{Mn}>\mathrm{Cu}>\mathrm{Ni}>\mathrm{Co}>\mathrm{Cd}>\mathrm{Pb}$.

В большинстве изученных образцов пылевых частиц на первом - втором месте по содержанию находились цинк и железо (на пр. Горняков - марганец), на третьем - марганец (на пр. Горняков - цинк), на четвертом - медь, на пятом - никель, на шестом свинец (на территории отвалов - кобальт), на седь142 мом - кобальт (на отвалах - кадмий), на восьмом кадмий (на отвалах - свинец).

Концентрация всех изученных металлов в пыли на отвалах карьера выше по сравнению с пылью на улицах города, за исключением свинца и железа.

\section{Заключение}

Почвы селитебной зоны г. Сибай загрязнены такими металлами, как медь, цинк, никель, кадмий, кобальт, марганец и свинец.

Пониженное содержание ряда ТМ (железа, кадмия, кобальта и подвижных форм никеля) в почвах под кроной B. pendula Roth. по сравнению с открытыми участками подтверждает роль древесных растений в качестве барьера, защищающего почву от аэрогенного поступления токсикантов.

Медь, марганец, кобальт, никель накапливались преимущественно в листьях, цинк - в лубе и коре, свинец и кадмий - в коре B. pendula Roth. Выявлено 
высокое содержание цинка в коре и лубе березы повислой. Данный результат, возможно, объясняется тем, что береза не только толерантна к цинку [12; 13], но и является его накопителем. Вопросы механизмов металлического гомеостаза в березе требуют специального рассмотрения.

Центральная часть города является более запыленной по сравнению с территорией отвалов Сибайского карьера в связи с их расположением за чертой города на открытой и интенсивно проветриваемой местности, что способствует рассеиванию пыли. Вместе с тем частицы пыли на территории отвалов карьера в значительно большей степени загрязнены марганцем, кобальтом и кадмием по сравнению с пылью в центральной части города.

Приведенные результаты исследований подтверждают положительную роль зеленых насаждений в борьбе с пылью на урбанизированных территориях. Показана перспективность использования березы повислой в качестве вида аккумулянта-фиторемедианта при озеленении городских территорий Зауральского региона Республики Башкортостан.

\section{Список литературы:}

1. Геохимия окружающей среды. М.: Недра, 1990. $335 \mathrm{c}$.

2. Перельман А.И., Касимов Н.С. Геохимия ландшафта. М.: Астрея-2000, 1999. 768 с.

3. Орлов Д.С., Садовникова Л.К., Лозановская И.Н. Экология и охрана биосферы при химическом загрязнении. М.: Высшая школа, 2004. 334 с.

4. Микроэлементы в окружающей среде: биогеохимия, биотехнология и биоремедиация / под ред. М.Н.В. Прасада, К.С. Саджвана, Р. Найду. М.: Физматлит, 2009. $816 \mathrm{c.}$

5. Новиков С.М., Иваненко А.В. Оценка ущерба здоровью населения Москвы от воздействия взвешенных веществ в атмосферном воздухе // Гигиена и санитария. 2009. № 6. С. 41-43.

6. Чудинова О.Н. Влияние техногенного загрязнения атмосферного воздуха на здоровье населения Забайкалья (на примере г. Улан-Удэ): автореф. дис. ... канд. биол. наук. Улан-Удэ, 2008. 22 с.

7. Health Aspects of Air Pollution - answers to follow-up questions from CAFE // Report on a WHO working group meeting Bonn, Germany, 15-16 January 2004. Respiratory effects are associated with the number of ultrafine particles / A. Peters [et al.] // American Journal of Respiratory and Critical Care Medicine. 1997. № 155. P. 1376-1383.

8. Дорн О.Ю. Биохимические и иммунологические факторы патогенеза гастропатий у больных профессиональной хронической пылевой патологией легких: автореф. дис. ... канд. мед. наук. Новосибирск, 2007. 22 с.

9. Куценогий К.П., Куценогий П.К. Аэрозоли Сибири. Итоги семилетних исследований // Сибирский экологический журнал. 2000. № 1. С. 11-20.

10. Опекунова М.Г. Диагностика техногенной трансформации ландшафтов на основе биоиндикации: автореф. дис. ... д-ра геогр. наук. СПб., 2013. $36 \mathrm{c}$.

11. Методические указания по оценке степени опасности загрязнения почвы химическими веществами. М.: Колос, 1987. 64 с.
12. Brown V.N., Wilkins D.A. Zinc tolerance of mycorrhizal Betula spp. // New Phytologist. 1985. Vol. 99. P. 101-106.

13. Denny H.J., Wilkins D.A. Zinc tolerance in Betula species. I: Effect of external concentration of zinc on growth and uptake // New Phytologist. 1987. Vol. 106. P. 517-522.

14. Eltrop L., Brown G., Joachim O., Brinkmann K. Lead tolerance of Betula and Salix in the mining area of Mechernich (Germahy) // Plant Soil. 1991. Vol. 131. P. 275-285.

15. Радостева Э.Р. Эколого-биологическая характеристика насаждений сосны обыкновенной (Pinus sylvestris L.) и березы повислой (Betula pendula Roth.) при лесной рекультивации отвалов горнодобывающей промышленности (Республика Башкортостан): автореф. дис. ... канд. биол. наук. Уфа, 2011. 23 с.

16. Агрохимические методы исследования почв. М.: Наука, 1975. 656 с.

17. Экологический мониторинг: учебно-методическое пособие. Изд. 3-е, испр. и доп. / под ред. Т.Я. Ашихминой. М.: Академический Проект, 2006. $416 \mathrm{c}$.

18. Предельно допустимые концентрации и условно-допустимые концентрации химических веществ в почве: гигиенические нормативы. М.: Федеральный Центр гигиены и эпидемиологии, 2006. 15 с.

19. Опекунова М.Г., Алексеева-Попова Н.В., Арестова И.Ю., Грибалев С.В., Краснов Д.А., Бобров Д.Г., Осипенко О.А., Соловьева Н.И. Тяжелые металлы в почве и растениях Южного Урала: экологическое состояние эталонных территорий // Вестник Санкт-Петербургского университета. 2001. № 7 (31). С. 45-53.

20. Виноградов А.П. Среднее содержание химических элементов в главных типах изверженных пород земной коры // Геохимия. 1962. № 7. С. 555-571.

21. Diskinson N.M., Lepp N.W. Metals and trees: impact, responses to exposure and exploitation of resistance traits // Contaminated Soils / Ed. by R. Prost Paris: INRA, 1997. P. 247.

22. Turner A.P., Dickinson N.V. Survival of Acer pseudoplatanus L. (sycamore) seedlings on metalliferous soils // New Phytologist. 1993. Vol. 123. P. 509.

23. Прохорова Н.В., Матвеев Н.М., Павловский В.А. Аккумуляция тяжелых металлов дикорастущими и культурными растениями в лесостепном и степном Поволжье. Самара: Самар. ун-т, 1998. 97 с.

24. Алексеев Ю.В. Тяжелые металлы в агроландшафте. СПб.: Изд-во ПИЯФ РАН, 2008. 216 с.

25. Тарабрин В.П. Устойчивость древесных растений в условиях промышленного загрязнения: автореф. дис. ... д-ра биол. наук. Киев, 1974. 71 с.

26. Кабата-Пендиас А., Пендиас Х. Микроэлементы в почвах и растениях. М.: Мир, 1989. 439 с.

27. Ковальский В.В. Геохимическая экология. М.: Наука, 1974. 299 с.

28. Корлыханов М.С., Корлыханова Т.В. Пылезадерживающая способность листовой поверхности тополя свердловского серебристого пирамидального в условиях г. Екатеринбурга // Аграрный вестник Урала. 2008. № 10 (52). С. 93-94.

Публикация подготовлена в рамках поддержанного РФФИ и Правительством Республики Бацкортостан научного проекта 18-413-020004 p_a. 


\title{
ASSESSMENT OF ECOLOGICAL AND GEOCHEMICAL CONDITION OF SOILS AND DUST CONTENT OF ATMOSPHERIC AIR IN THE RESIDENTIAL ZONE OF THE MINING INDUSTRY CENTER
}

(C) 2018

Khasanova Rezeda Firgatovna, doctor of biological sciences, leading researcher

of Ecology and Environmental Management Laboratory; associate professor of Natural Sciences Department

Semenova Irina Nikolaevna, doctor of biological sciences, senior researcher

of Ecology and Environmental Management Laboratory; professor of Natural Sciences Department

Sibay Branch Institute of Strategic Studies of Republic of Bashkortostan

(Sibay, Republic of Bashkortostan, Russian Federation); Sibay Institute (Branch) of Bashkir State University

(Sibay, Republic of Bashkortostan, Russian Federation)

Rafikova Yuliya Samigullovna, candidate of biological sciences, senior researcher of Ecology and Environmental Management Laboratory

Sibay Branch Institute of Strategic Studies of Republic of Bashkortostan

(Sibay, Republic of Bashkortostan, Russian Federation)

Suyundukov Yalil Tukhvatovich, doctor of biological sciences, chief researcher

of Ecology and Environmental Management Laboratory; deputy director for scientific work

Sibay Branch Institute of Strategic Studies of Republic of Bashkortostan

(Sibay, Republic of Bashkortostan, Russian Federation); Sibay Institute (Branch) of Bashkir State University (Sibay, Republic of Bashkortostan, Russian Federation)

Ilyina Irina Valerievna, candidate of biological sciences, associate professor of Botany Department

Sibay Institute (Branch) of Bashkir State University (Sibay, Republic of Bashkortostan, Russian Federation)

Abstract. The research studies the content of heavy metals (HM) in soils of residential zones of Sibay - the mining industry center of the South-East of the Republic of Bashkortostan. It is shown that in soils under herbaceous vegetation there is an increased content of a number of HMS, such as copper, zinc and cadmium. At the same time the areas located under the crown of Betula pendula Roth. are less contaminated with HM compared to open areas. Reduced content of a number of metals (iron, cadmium, cobalt and mobile forms of Nickel) in soils under the crown of the Roth confirms the barrier role of woody plants that protect the soil from airborne toxicants. The study showed the prospects of using a birch as a type of accumulator-phytoremediant in the greening of the mining region urban areas of the Republic of Bashkortostan. Studies of TM content in organs and tissues have shown that representatives of the species growing in Sibay can accumulate a significant amount of phytotoxicants, especially zinc, the content of which ranged 1041-1855 mg/kg. One of the sources of the increased TM content in the leaves and the bark of trees is dust. The paper presents a comparative study of the dustiness of birch leaves growing in the Central part of the city with heavy traffic and in the vicinity of the Sibay quarry, developing a Deposit of copper-zinc ore. The amount of dust on the leaves collected near the dumps of the Sibay quarry was $3,53 \pm 0,64 \mathrm{~g} / \mathrm{m}^{2}$, which is less than in the Central part of the city, where this figure reached $41,04 \pm 10,38 \mathrm{~g} / \mathrm{m}^{2}$. Obviously, this is due to the fact that the dumps of the Sibay quarry are located in an open and intensively ventilated area, which explains the strong dispersion of dust. At the same time dust particles near the quarry dumps are much more contaminated with manganese, cobalt and cadmium than in the Central part of the city.

Keywords: heavy metals; pollutants; maximum permissible concentration; regional geochemical background; mining industry; dust content of atmospheric air; environmental monitoring; soils; woody plants; birch; herbaceous vegetation; Sibay; Republic of Bashkortostan.

УДК 574.52

DOI 10.24411/2309-4370-2018-14125

Статья поступила в редакцию 03.07.2018

\section{АНАЛИЗ СТЕПЕНИ РЕАГИРОВАНИЯ ГИДРОБИОНТОВ НА СОДЕРЖАНИЕ ХИМИЧЕСКИХ ВЕЩЕСТВ} В ВОДЕ ВЕРХНЕГО И СРЕДНЕГО ТЕЧЕНИЙ РЕКИ БЕЛОЙ (РЕСПУБЛИКА БАШКОРТОСТАН) (C) 2018

\author{
Чаус Борис Юрьевич, кандидат биологических наук, доцент кафедры биологии \\ Стерлитамакский филиал Башкирского государственного университета \\ (2. Стерлитамак, Республика Башкортостан, Российская Федерация)
}

Аннотащия. В статье приводится анализ биоиндикационных возможностей гидробионтов различных си-
стематических категорий для оценки и прогноза антропогенного загрязнения реки Белой (верхнего и средне-
го течений) в ходе экологического мониторинга природных вод Республики Башкортостан. Сбор гидробион-
тов и анализ встречаемости (в долях единицы) 30 видов беспозвоночных животных из отрядов Ругатіdеl-
loida, Littorinimorpha, Pulmonata, Plecoptera, Ephemeroptera, Trichoptera и 12 видов высшей водной paститель-
ности проводился с 2005 по 2017 годы в районах 10 государственных водных постов на реке Белой. В каче-
стве гидрохимических показателей на изученных створах использовались данные из ежегодных Государ-
ственных докладов «О состоянии природных ресурсов и окружающей среды Республики Башкортостан» по 144 Самарский научный вестник. 2018. Т. 7, № 4 (25) 